Original Paper

\title{
Penyuluhan Penanganan Penyakit Scabies di Yayasan Pondok Pesantren Ma. Ishlahil Athfal Rumak Lombok Barat
}

\author{
Edy Kurniawan $^{1 *}$, Aini ${ }^{1}$, Sri Rahmawati ${ }^{2}$ \\ ${ }^{1}$ Program Studi Analis Kesehatan, Politeknik Medica Farma Husada Mataram, Indonesia \\ ${ }^{2}$ Program Studi Farmasi, Politeknik Medica Farma Husada Mataram, Indonesia
}

DOI: $10.29303 /$ jpmpi.v2i1.320

Sitasi: Kurniawan, et, al. (2019). Penyuluhan Penanganan Penyakit Scabies di Yayasan Pondok Pesantren Ma. Ishlahil Athfal Rumak Lombok Barat. Jurnal Pengabdian Magister Pendidikan IPA (JPMPI). (2) 1. pp. 22-24

*Corresponding Author: Edy Kurniawan, Program Studi Analis Kesehatan, Politeknik Medica Farma Husada Mataram, Indonesia; Email: edykurniawanw@yahoo.com

\begin{abstract}
Abstrak: Tujuan kegiatan pengabdian masyarakat ini adalah Memberikan pengetahuan kepada seluruh siswa tentang penyakit kulit skabies meliputi pengertian, gejala, tanda, cara penularan, dan pengobatan serta pencegahannya. Manfaat diselenggarakannya kegiatan ini untuk meningkatkan pemahaman siswa/masyarakat pesantren tentang penyakit scabies dan mampu menerapkan pola hidup sehat serta lingkungan bersih dalam kehidupan sehari-hari. Kegiatan penyuluhan ini merupakan suatu upaya untuk menangani permasalahan penyakit kulit yang sering terjadi di lingkungan pondok pesantren MA. Ishlahil Athfal dengan target sasaran adalah guru dan siswa. Langkah-langkah pelaksanaan kegiatan adalah melakukan pertemuan dengan kepala sekolah dan perwakilan guru Pondok Pesantren Ma. Ishlahil Atfhfal Rumak Lombok Barat guna meminta izin melakukan kegiatan penyuluhan dan membicarakan masalah teknis pelaksanaan. Dari hasil diskusi didapatkan kesepakatan kegiatan penyuluhan dilaksanakan pada hari sabtu, 23 maret 2019 pukul 09.00 s/d selesai dengan target siswa kelas XII sebanyak 31 orang dengan tema Penyuluhan penanganan penyakit kulit (skabies). Kegiatan penyuluhan berjalan dengan lancar dimana para siswa sangat antusias dalam memperhatikan materi yang disampaikan, ada beberapa pertanyaan yang ternyata juga diajukan oleh para siswa karena rasa keingintauannya. Para siswa cukup terkejut dan takut saat melihat beberapa contoh penyakit kulit skabies yang ada dalam presentasi kami. Oleh karena itu penyuluhan tentang penyakit kulit skabies ini mampu memberikan tambahan pengetahuan bagi para siswa sehingga mereka dapat mencegah terinfeksi dan penularan penyakit skabies tersebut.
\end{abstract}

Keywords: Penyakit Scabies; Penyuluhan; Penanganan

\section{Pendahuluan}

Scabies adalah penyakit kulit yang disebabkan oleh sarcoptes scabiei. Skabies dapat terjadi pada laki-laki dan perempuan, semua geografi daerah, umur, ras, kelas sosial, daerah yang padat dan sanitasi yang buruk. Skabies merupakan penyakit zoonosis yang menyerang kulit, disebabkan tungau (Sarcoptes scabiei) dan dapat menyerang orang di seluruh dunia. Skabies merupakan 1 dari 6 penyakit terbesar parasit kulit epidermis yang lazim ditemukan pada populasi miskin (Wardhana et al., 2016).
Angka kejadian skabies sering terjadi pada orang-orang yang tinggal bersama di fasilitas tertentu, seperti fasilitas asrama, pondok pesantren, rumah jompo, rumah sakit, rawat inap, rumah tahanan dan fasilitas lainnya. hal ini disebabkan oleh kepadatan penghuni yang tinggi dapat mempengaruhi perkembangan skabies. Menurut Soedarto pada tahun 2009, angka kejadian skabies telah diperkirakan 300 juta kasus skabies terjadi secara epidemi di rumah jompo, rumah sakit, fasilitas rawat inap, dan lembaga lainnya. Prevalensi skabies di puskesmas seluruh Indonesia pada tahun 1987 adalah 5,6\% - 12,95\% 
dengan menduduki urutan ketiga dari 12 penyakit kulit tersering (Wardhana et al., 2016).

Prevalensi penyakit skabies di Pondok Pesantren Ma. Ishlahil Atfhfal Rumak Kabupaten Lombok Barat cukup tinggi yaitu sekitar $60 \%$ dimana perilaku sehat (meliputi ; pengetahuan, sikap, perilaku) dan sanitasi lingkungan (meliputi sanitasi kamar atau asrama, sanitasi kamar mandi dan penyediaan air bersih) menjadi faktor yang mempengaruhi terjadinya skabies.Yayasan pondok pesantren islahil atfal merupakan salah satu sekolah yang menjadi tempat bagi siswa-siswa menuntut ilmu yang berasal dari berbagai daerah di NTB, sehingga untuk mencegah kejadian tersebut maka dilakukan penyuluhan kesehatan tentang penyakit skabies dan cara penanggulangan penyakit tersebut.

\section{Metode Pelaksanaan}

Perwakilan tim panitia yang diwakili oleh BEM Politeknik Medica Farma Husada Mataram melakukan pertemuan dengan kepala sekolah dan perwakilan guru Pondok Pesantren Ma. Ishlahil Atfhfal Rumak Lombok Barat guna meminta izin melakukan kegiatan penyuluhan dan membicarakan masalah teknis pelaksanaan. Dari hasil diskusi didapatkan kesepakatan kegiatan penyuluhan dilaksanakan pada hari sabtu, 23 maret 2019 pukul $09.00 \mathrm{~s} / \mathrm{d}$ selesai dengan target siswa kelas XII sebanyak 31 orang dengan tema Penyuluhan penanganan penyakit kulit (skabies).

Metode kegiatan yang dilakukan pada penyuluhan kali ini adalah dengan cara melakukan presentasi sesuai dengan tema dengan menggunakan media powerpoint sehingga akan lebih menarik perhatian para siswa. Untuk mengetahui tingkat penyerapan materi yang telah diberikan, maka diajukan dua pertanyaan kepada para siswa, bagi siswa yang dapat menjawab dengan benar maka diberi hadiah. Setelah melakukan presentasi, kemudian melakukan pemeriksaan tekanan darah, golongan darah, dan pemberian vitamin gratis.

\section{Hasil dan Pembahasan}

Kegiatan penyuluhan penyakit kulit skabies telah dilaksananakan pada hari sabtu tanggal 23 maret 2019 di Pondok Pesantren Ma. Ishlahil Atfhfal Rumak Lombok Barat pukul 9.00-12.00 WITA. Kegiatan penyuluhan ini disambut dengan sangat baik oleh kepala sekolah, guru, maupun siswa siswi di MA. Islahil Atfal. Ruangan yang digunakan adalah ruang aula yang sudah lengkap dengan peralatan LCD proyector, dan pengeras suara sehingga mempermudah bagi penyuluh untuk melakukan kegiatan ini. Para siswa duduk dengan tertib yang kemudian dilakukan perkenalan dari penyuluh sehingga tercipta suasana yang akrab dan menyenangkan, dengan ada sedikit permainan yang dilakukan agar para siswa bisa fokus dalam memperhatikan materi yang akan disampaikan.

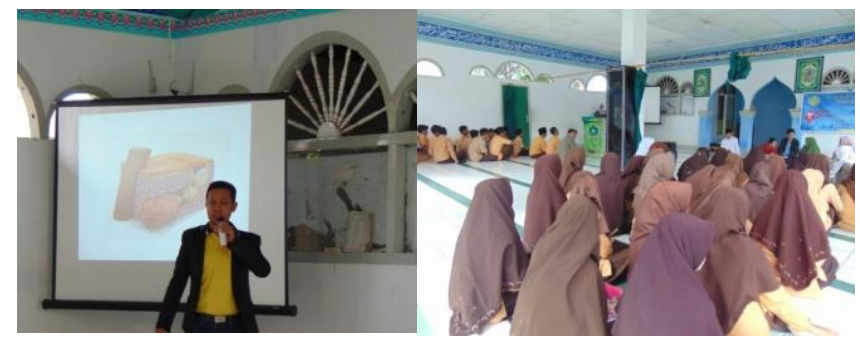

Gambar 1. Kegiatan Penyuluhan

Kegiatan penyuluhan berjalan dengan lancar dimana para siswa sangat antusias dalam memperhatikan materi yang disampaikan, ada beberapa pertanyaan yang ternyata juga diajukan oleh para siswa karena rasa keingintauannya. Para siswa cukup terkejut dan takut saat melihat beberapa contoh penyakit kulit skabies yang ada dalam presentasi kami. Oleh karena itu penyuluhan tentang penyakit kulit skabies ini mampu memberikan tambahan pengetahuan bagi para siswa sehingga mereka dapat mencegah terinfeksinya dan mencegah penularan penyakit skabies tersebut.

Secara umum kegiatan penyuluhan ini berjalan dengan baik tanpa hambatan, tetapi karena keterbatasan waktu maka tidak dilakukan posttest untuk menilai pemahaman materi yang disampaikan bagi semua peserta. Untuk melihat pemahaman terhadap materi yang disampaikan, presentator hanya memberikan 2 pertanyaan saja yang kemudian akan dijawab oleh siswa, bagi siswa yang dapat menjawab dengan benar maka mendapatkan hadiah.

Setelah dilakukan penyuluhan materi penyakit kulit skabies, penyuluh bersama panitia 
melakukan pemeriksaan tekanan darah, golongan darah, dan pemberian vitamin gratis kepada peserta kegiatan. Hal ini sangat menarik bagi para siswa, dan guru dimana mereka baru pertama kali mendapatkan kegiatan seperti ini di lingkungan sekolah.

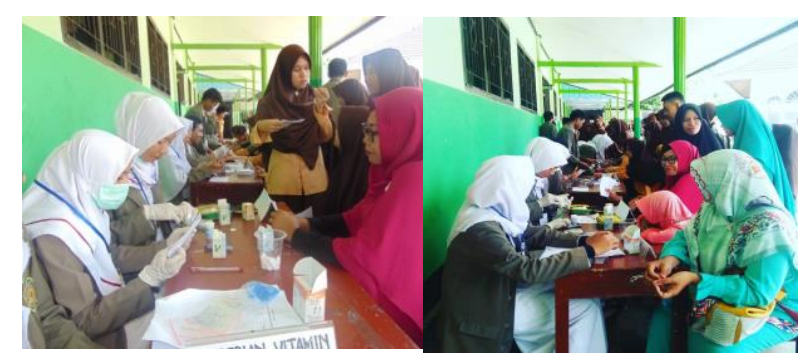

Gambar 2. Pemeriksaan Kesehatan \& Pengobatan Gratis
Politeknik Medica Farma Husada Mataram yang telah memberi dukungan financial terhadap kegiatan pengabdian masyarakat ini.

\section{Daftar Pustaka}

Soedarto. 2009. Penyakit Menular di Indonesia. Sagung Seto. Jakarta.

Tumenggung, I. 2017. Masalah Gizi Dan penyakit Menular Pasca Bencana. Health and Nutritions Journal. 3(1).

Wardhana, A, H., Manurung, J., Iskandar, T. 2006. Skabies: Tantangan Penyakit Zoonosis Masa Kini dan Masa Datang. Wartazoa (16)1: 40-52.

\section{Kesimpulan}

Kegiatan penyuluhan penyakit kulit skabies yang telah dilakukan di Pondok Pesantren MA. Islahil Atfal ini berjalan dengan lancar tanpa halangan suatu apapun. Pihak sekolah sangat berterimakasih atas materi yang telah diberikan sehingga dapat membantu pihak sekolah untuk dapat mengingatkan kepada para siswa siswinya dalam menjaga kesehatan kulit dan lingkungan, sehingga harapannya tidak ada lagi siswa yang sakit kulit scabies dan tidak tertular penyakit tersebut.

Para siswa pada akhir kegiatan juga sesuai target yang diharapkan yaitu mereka mampu memahami tentang penyakit kulit scabies dan mampu memahami kebersihan diri dan lingkungan.

\section{Saran}

Diharapkan adanya penyuluhan dengan materi lain yang dapat dilakukan di MA. Islahil Atfal atau pondok pesantren lainnya pada waktu yang akan datang.

\section{Ucapan Terima Kasih}

Penulis mengucapkan terima kasih kepada Lembaga Penelitian \& Pengabdian Masyarakat 